\title{
Methane, nitrous oxide emissions and mitigation strategies for livestock in developing countries: A review
}

\author{
F. Forabosco ${ }^{1,2 \#}$, Zh. Chitchyan ${ }^{1} \&$ R. Mantovani ${ }^{2}$ \\ ${ }^{1}$ Department of Private Husbandry, Armenian National Agrarian University, 74, Teryan, 0009, Yerevan, Armenia. \\ ${ }^{2}$ Department of Agronomy Food Natural Resources Animal Environment, University of Padova, Viale dell' Universita' 16, \\ Agripolis, 35020 Legnaro, Padova, Italy.
}

(Received 9 February 2017; Accepted 19 March 2017; First published online 30 March 2017)

Copyright resides with the authors in terms of the Creative Commons Attribution 4.0 South African Licence.
See: http://creativecommons.org/licenses/by/4.0/za
Condition of use: The user may copy, distribute, transmit and adapt the work, but must recognise the authors and the South African
Journal of Animal Science.

\begin{abstract}
Methane $\left(\mathrm{CH}_{4}\right)$ and nitrous oxide $\left(\mathrm{N}_{2} \mathrm{O}\right)$ are two important greenhouse gases (GHGs) that are emitted into the atmosphere by livestock during the process of enteric fermentation and manure management. Developing countries produce a large quantity of those emissions, caused mainly by inefficient animal rearing systems, feed production and manure management. This paper outlines the $\mathrm{CH}_{4}$ and $\mathrm{N}_{2} \mathrm{O}$ emitted from livestock in developing countries and the mitigation actions that could be put in place to reduce atmospheric emissions and increase animal productivity. Emission intensity expresses emission $\left(\mathrm{CO}_{2}\right.$ equivalents) per unit of product and describes it in relation to the capacity of local animals to produce from local resources. Developing countries are characterized by low production per animal and, consequently, high emission intensity. The emission intensity of dairy cattle in developing countries ranges from 2 to $9 \mathrm{~kg}$ $\mathrm{CO}_{2}$-eq/kg fat and protein corrected milk (FPCM) and in only a few cases is below $2 \mathrm{~kg} \mathrm{CO}{ }_{2}$-eq $/ \mathrm{kg} \mathrm{FPCM}$. In sub-Saharan Africa, the average emission intensity is $7.5 \mathrm{~kg} \mathrm{CO}$-eq $^{-} \mathrm{kg} F P C M$ for dairy cattle, $71 \mathrm{~kg} \mathrm{CO}_{2^{-}}$ eq $/ \mathrm{kg}$ of carcass weight for beef cattle, $6.9 \mathrm{~kg} \mathrm{CO}$-eq $/ \mathrm{kg}$ FPCM for sheep and goats, and $5 \mathrm{~kg} \mathrm{CO}$-eq/ $/ \mathrm{kg}$ eggs for chickens. Taking into account the limited economic and technical resources in most developing countries, the application of appropriate mitigation tools is recommended to reduce the emissions of $\mathrm{CH}_{4}$ and $\mathrm{N}_{2} \mathrm{O}$ gases in the atmosphere. Increasing livestock productivity through selection and feeding is the most effective tool to reduce emission intensity.
\end{abstract}

Keywords: Breeding, emission intensity, fermentation, greenhouse gas, manure

\#Corresponding author: forabosco@yahoo.com

\section{Introduction}

In developing countries, the human population is likely to increase to around two billion from now to 2050 , as will the livestock sector, with a livestock population of around 34 billion animals by 2050 (Alexandratos \& Bruinsma, 2012). In those countries, the numbers of livestock animals are rising to respond to the growing demand for food. Inefficiencies in the livestock systems and low investments in the sector cause the rapid increase of greenhouse gases (GHGs) emitted in the atmosphere (Scholtz et al., 2013a).

The list of gases that are considered the main sources of global warming includes carbon dioxide $\left(\mathrm{CO}_{2}\right)$, methane $\left(\mathrm{CH}_{4}\right)$, nitrous oxide $\left(\mathrm{N}_{2} \mathrm{O}\right)$, and other GHGs. At global level, livestock emits in the atmosphere $18 \%$ of the total anthropogenic emissions of GHGs. Enteric fermentation and manure represent $80 \%$ of the total $\mathrm{CH}_{4}$ emitted by the agricultural sector and 35 to $40 \%$ of total anthropogenic $\mathrm{CH}_{4}$ emission. Furthermore, livestock activities contribute substantially to the emission of $\mathrm{N}_{2} \mathrm{O}$, accounting for almost two thirds of all anthropogenic $\mathrm{N}_{2} \mathrm{O}$ emissions and 75 to $80 \%$ of agricultural emissions (Steinfeld et al., 2006). In addition, in developing countries the total $\mathrm{CH}_{4}$ and $\mathrm{N}_{2} \mathrm{O}$ emissions will increase in future, mainly because of the expected rise in the number of livestock.

The measure of how much heat these two greenhouse gases could trap in the atmosphere in 100 years is named global warming potential (GWP). For $\mathrm{CH}_{4}$ and $\mathrm{N}_{2} \mathrm{O}$, GWP is 25 and 298 times greater, respectively, than $\mathrm{CO}_{2}$. These gases have high capacity to reflect infrared radiation back to earth, the main factor that is responsible for the increase in temperature on earth (Iwata \& Okada, 2010; IPCC, 2014).

Greenhouse gasses have been studied extensively in the last decade, but the number of reviews on GHG emissions of livestock in developing countries is limited. To the authors' knowledge, only a few 
emission studies have focused on developing countries in recent years, which are large sources of $\mathrm{CH}_{4}$ and $\mathrm{N}_{2} \mathrm{O}$ emissions and would benefit most from appropriate mitigation actions.

The first section of this paper therefore briefly reviews some complex relations between livestock, methane, and $\mathrm{N}_{2} \mathrm{O}$ in developing countries. These have been discussed extensively by Steinfeld et al. (2006). For this reason, the authors start from here to investigate new findings in this area that have occurred in the last decade. The second section reviews the literature about $\mathrm{CH}_{4}$ emission per species in developing countries. Particular attention is dedicated to the species that are most diffuse in those countries. The third section discusses feasible and economically sustainable mitigation strategies that could be put in place in developing countries to reduce GHG emissions and combat climate change.

\section{Methodology}

The methodology of this study consists of a literature review in the research fields of methane and $\mathrm{N}_{2} \mathrm{O}$ emissions, gas reduction strategies and livestock. The aim of the review is to give the current state of literature in the research fields in developing countries. The literature search was performed in 2016/2017 with the use of Web of Knowledge, Google Scholar, and Scopus. To quantify the emission intensities of ruminants, pigs and chickens in developing countries, the terms 'cattle', 'buffalo', 'sheep', 'goat', 'pig' and 'chicken' were combined with 'climate', 'greenhouse gas', 'methane', 'nitrous oxide' or 'mitigation' and 'developing country' or 'emerging economy'. In addition, the articles included in the review met these inclusion criteria: i) they were published between 2006 and 2017, ii) they were published in the English language, iii) they were peer-reviewed and cited articles, and iv) they referred to developing countries and transition economies. One additional criterion for the comparison of results was that the emission intensity should be expressed in $\mathrm{CO}_{2}$ equivalents $\left(\mathrm{CO}_{2}\right.$-eq) per unit of product (i.e. $\mathrm{kg}$ fat and protein corrected milk (FPCM), kg of carcass weight, and kg of eggs). Emission intensity expresses the quantity of gases produced per animal for a unit of production. This measurement reflects most accurately the management, feeding and manure systems of livestock in developing countries and the effects of a given mitigation practice (Hristov et al., 2013a). The results were analysed and the conclusions are presented and discussed in this paper critically.

\section{Methane and nitrous oxide emissions in developing countries Importance of both greenhouse gases}

Both $\mathrm{CH}_{4}$ and $\mathrm{N}_{2} \mathrm{O}$ have important effects on the livestock industry in developing countries. International policy discussions have focused in the last two decades on non- $\mathrm{CO}_{2}$ emissions such as $\mathrm{CH}_{4}$ and $\mathrm{N}_{2} \mathrm{O}$ because these are less expensive to mitigate than $\mathrm{CO}_{2}$ emissions (Shafer et al., 2011; Hristov et al., 2013a). In addition, reduction of $\mathrm{CH}_{4}$ and $\mathrm{N}_{2} \mathrm{O}$ emissions could be economically advantageous for developing countries and environmentally beneficial (Key \& Tallard, 2012). Furthermore, $\mathrm{CH}_{4}$ and $\mathrm{N}_{2} \mathrm{O}$ together represent a large quota of GHGs emitted by livestock into the atmosphere, while in nonindustrialized countries $\mathrm{CO}_{2}$ arises mainly from metabolism of plant-derived feedstuffs, and is assumed to be zero, since the $\mathrm{CO}_{2}$ that is photosynthesized by plants is returned completely to the atmosphere as respired $\mathrm{CO}_{2}$ (Herrero et al., 2011). Lastly, consumers and retailers in developing countries are becoming more aware of the carbon footprint of food and the important positive implication that animals could have on converting human-inedible by-products (e.g. grass) into high-quality human food and products (e.g. milk, meat, wool, and eggs).

\section{Sources of methane and nitrous oxide, enteric and manure emissions}

Methane and $\mathrm{N}_{2} \mathrm{O}$ are emitted from natural and anthropogenic sources. Natural sources of $\mathrm{CH}_{4}$ emission represent a small portion of total $\mathrm{CH}_{4}$ emission in the atmosphere. They are originated mainly by permafrost, termites, oceans, freshwater bodies, gas hydrates, wetlands and non-wetland soils, volcanoes, and wildfires (Kirschke et al., 2013). Anthropogenic sources represent a large portion of total $\mathrm{CH}_{4} \mathrm{emission} \mathrm{in}$ the atmosphere. They are generated by biomass burning, fossil fuel, cultivations, wastes, and animal husbandry (enteric fermentation and manure management). Enteric fermentation is the process that affects mainly ruminants, and is the result of complex microbiological activity. During this process, which occurs in the rumen in anaerobic conditions, cellulose and other large molecules are broken down, causing the release of hydrogen. Carbon dioxide and hydrogen are converted by methanogenic archaea to methane, which is expelled through the mouth and nose in the process of eructation (Aluwong et al., 2011). Methane from manure is generated in anaerobic conditions through a decomposition process of organic matter in faecal and bedding material. The anaerobic environment is a precondition for the production of $\mathrm{CH}_{4}$ via microbial metabolism of organic material. The manure is degraded into substances such as volatile acids, and these substances are used by bacteria to produce $\mathrm{CH}_{4}$ (Chadwick et al., 2011; Petersen et al., 2013). 
The emission of $\mathrm{N}_{2} \mathrm{O}$ occurs from livestock bedding, solid manure, and surface layers of stored slurry, and in soil after the addition of manure. Most inorganic nitrogen $(\mathrm{N})$ in slurry and fresh solid manure is in the form of ammonium. Transformation from ammonium to nitrate via nitrification is a source of $\mathrm{N}_{2} \mathrm{O}$, as well as the production of $\mathrm{NO}_{3}$ (nitrate), which is a source of $\mathrm{N}$ for the denitrification (the biological reduction of nitrate to $\mathrm{N}_{2}$ gas) process, which increases further the $\mathrm{N}_{2} \mathrm{O}$ production through incomplete denitrification (Chadwick et al., 2011; Köster et al., 2015). The quantity of $\mathrm{CH}_{4}$ and $\mathrm{N}_{2} \mathrm{O}$ produced by manure is sensitive to environmental conditions such as temperature, manure composition and its management. Correct management of manure together with low temperature can be used as an efficient mitigation tool (Gerber et al., 2013a; Petersen et al., 2013). In developing countries, the large emitters of $\mathrm{CH}_{4}$ from enteric fermentation are ruminants (cattle, buffalo, sheep, and goats), while for manure, all domestic species contribute to the production of $\mathrm{CH}_{4}$ and $\mathrm{N}_{2} \mathrm{O}$ (Gerber et al., 2013b).

\section{Projections of methane and nitrous oxide emissions in developing countries}

Greenhouse gas emissions from the livestock sector in developing countries continue to rise, and the biggest increase is from $\mathrm{CH}_{4}$, followed by $\mathrm{N}_{2} \mathrm{O}$ (Gerber et al., 2013b; Caro et al., 2014; Bhatta et al., 2015). From 2005 to 2030, $\mathrm{CH}_{4}$ emissions from enteric fermentation are projected to grow. The developing regions with the largest $\mathrm{CH}_{4}$ emissions will be Africa (48\%), non-OECD (Organisation for Economic Co-operation and Development) Asia (35\%), and the Middle East (24\%). In the same period, emissions from manure $\left(\mathrm{CH}_{4}\right.$ and $\mathrm{N}_{2} \mathrm{O}$ ) are expected to increase in developing regions by $41 \%, 38 \%, 28 \%$ and $24 \%$ in non-OECD Asia, Africa, Central and South America, and the Middle East, respectively (EPA, 2011). In another study, similar results were found when $\mathrm{CH}_{4}$ emission was estimated in Africa. In 2000-2030, Herrero et al. (2008) estimated an average increase of $40 \%$ in $\mathrm{CH}_{4}$ emission. $\mathrm{By} 2030, \mathrm{CH}_{4}$ emission is likely to have increased by $79 \%, 69 \%$, and $16 \%$ in West Africa, Southern Africa, and Central Africa, respectively. In a fifty-year study, the analysis of $\mathrm{CH}_{4}$ emissions in developing regions has shown an increase, particularly in more recent years (Caro et al., 2014). Total $\mathrm{CH}_{4}$ emissions in Africa, Central, South America, the Middle East, and nonOECD Asia was $56 \%$ in $1990,54.7 \%$ in 2010, and will increase to $66.8 \%$ in 2030 , with the small decrease in 2010 because of the world financial banking crisis, which started in 2008 and affected all sectors, including livestock production in developing countries (Török et al., 2015). Caro et al. (2014) analysed $\mathrm{N}_{2} \mathrm{O}$ emissions in developing countries between 1961 and 2010, highlighting an increase of $\mathrm{N}_{2} \mathrm{O}$ from $307.5 \mathrm{Mt} \mathrm{CO}_{2}$-eq to $701.96 \mathrm{Mt} \mathrm{CO}_{2}$-eq with positive trends for the years afterwards.

\section{Emissions per species Dairy cattle}

The demand for dairy products in developing countries is increasing, but the level of dairy cattle productivity is relatively stable, and ranges between 1300 and $5000 \mathrm{~kg}$ milk per milking cow per year (Alexandratos \& Bruinsma, 2012). For this reason, to compensate for the growing demand for dairy products, the number of dairy cattle is increasing. In industrialized countries, the situation is the opposite, because productivity per animal has increased constantly in the last 30 years, owing to a continual improvement in breeding, feeding, and management (Nicolazzi et al., 2011; Lehrman et al., 2014), and the number of dairy cattle is decreasing. A study conducted by Opio et al. (2013) investigated the gas emissions per unit of milk produced in various countries, and identified large differences in developing regions, ranging from 2 to $9 \mathrm{~kg}$ $\mathrm{CO}_{2}$-eq $/ \mathrm{kg}$ of FPCM. In sub-Saharan Africa, South Asia, and NENA (Near East and North Africa), GHG emissions were on average 7.5, 4.6, and $3.7 \mathrm{~kg} \mathrm{CO}_{2}$-eq/ $\mathrm{kg}$ FPCM at farm gate, respectively (Gerber et al., 2010). In a simulation study in Armenia, a developing country in East Europe, the emissions from improved dairy cattle were $2.4 \mathrm{~kg} \mathrm{CO}$-eq $/ \mathrm{kg}$ of milk at $16{ }^{\circ} \mathrm{C}$, a value between that of the emissions of developed countries in East Europe and the developing countries of the Middle East (Forabosco et al., unpublished). Similar results were obtained in the district of Amend (India), where the carbon footprint of milk production under the smallholder dairy system was $2.2 \mathrm{~kg} \mathrm{CO}$-eq/kg FPCM (Garg et al., 2016). In a lifecycle assessment study (cradle to farm gate) of smallholder dairy cattle farms in India using a large dataset and comparing two levels of feeding management (no improvement vs improvement of feeding), Garg et al. (2014) found a reduction of emission intensity from 1.8 (with no feeding improvement) to $1.2 \mathrm{~kg} \mathrm{CO}$-eq/ $/ \mathrm{kg}$ FPCM (accounting for feeding improvement), clearly indicating that correct and balanced feeding has a positive effect on reducing gas emissions. Gerber et al. (2011) pointed out that for cows producing up to $1000 \mathrm{~kg} \mathrm{FPCM}$, the incidences of $\mathrm{CH}_{4}$ and $\mathrm{N}_{2} \mathrm{O}$ on total gas emissions are $52 \%$ and $42 \%$, respectively. With productivity between 1001 and $3000 \mathrm{~kg} \mathrm{FPCM}$ the incidence of $\mathrm{CH}_{4}$ and $\mathrm{N}_{2} \mathrm{O}$ is reduced to $50 \%$ and $32 \%$, respectively, and from 3001 to $5000 \mathrm{~kg} \mathrm{FPCM}$ it is further lowered to $47 \%$ and $26 \%$, respectively. Furthermore, $\mathrm{CH}_{4}$ and $\mathrm{N}_{2} \mathrm{O}$ emissions decrease with the increase of milk productivity and at up to $2000 \mathrm{~kg}$ FPCM/cow/year the emissions ranged from $12 \mathrm{~kg} \mathrm{CO}$-eq $/ \mathrm{kg} \mathrm{FPCM}$ to about $3 \mathrm{~kg} \mathrm{CO}$-eq $/ \mathrm{kg} \mathrm{FPCM}$, while at around $6000 \mathrm{~kg} \mathrm{FPCM} / \mathrm{cow} /$ year the emission was stabilized between 1.6 and $1.8 \mathrm{~kg} \mathrm{CO}$-eq/kg FPCM, 
similar to the trend found by Garg et al. (2014). In addition, management systems play an important role in $\mathrm{CH}_{4}$ and $\mathrm{N}_{2} \mathrm{O}$ emissions in developing counties. Extensive dairy production systems (i.e. pasture) have the highest emissions, while intensively managed dairy production systems have the lowest (Du Toit et al., 2013; Scholtz et al., 2013c; Knapp et al., 2014). In South Africa, Meissner et al. (2013a) found that in 2007 the emission intensity of $\mathrm{CH}_{4}$ from dairy cows not in milk recording (average production of $4590 \mathrm{~kg}$ milk per cow) and in milk recording (average production of $6950 \mathrm{~kg}$ milk per cow) were 1.6 and $1.4 \mathrm{CO}_{2}$-eq/ $/ \mathrm{kg}$ of milk, respectively. Neither emission intensity included $\mathrm{N}_{2} \mathrm{O}$ emission nor the milk was corrected for the contents of fat and protein. In a lifecycle assessment study conducted in smallholders dairying in Kenya, it was found that the average emission intensity for milk production was $2.0 \mathrm{~kg} \mathrm{CO}_{2}$-eq $/ \mathrm{kg} \mathrm{FPCM} \mathrm{(Weiler} \mathrm{et} \mathrm{al.,} \mathrm{2014),}$ while in another lifecycle assessment study conducted in Iran, values were low and ranged between $1.57 \mathrm{~kg}$ $\mathrm{CO}_{2}$-eq $/ \mathrm{kg} \mathrm{FPCM}$ at farm gate and $1.73 \mathrm{~kg} \mathrm{CO}$-eq $/ \mathrm{kg} \mathrm{FPCM}$ at the milk processing gate. Differences between the two lifecycle assessment studies were mainly the result of differences in environment, feeding and management systems (Daneshi et al., 2014). Table 1 summarizes the emissions for the most common species raised in developing countries and regions.

\section{Beef cattle}

Beef cattle have the highest emission intensity in developing countries (Gerber et al., 2013b; Caro et al., 2014; Patra, 2014). In those countries, total emissions from beef cattle almost doubled in four decades, from $663.95 \mathrm{MtCO}_{2}$-eq in 1961 to $1286.60 \mathrm{MtCO}_{2}$-eq in 2010, while the emissions per ton of meat decreased from 75.37 ( $\mathrm{CO}_{2}$-eq/ton of product) in 1961 to 35.48 (t CO -eq/ton of product) in 2010 (Caro et al., 2014). In particular, beef production has the highest emission intensities in South Asia $(76 \mathrm{~kg} \mathrm{CO}$-eq $/ \mathrm{kg}$ carcass weight $(\mathrm{CW})$, Latin America and the Caribbean $\left(72 \mathrm{~kg} \mathrm{CO}{ }_{2}-\mathrm{eq} / \mathrm{kg} \mathrm{CW}\right)$, and sub-Saharan Africa $\left(71 \mathrm{~kg} \mathrm{CO}_{2^{-}}\right.$ eq $/ \mathrm{kg} \mathrm{CW}$ ), and the lowest, only $48 \mathrm{~kg} \mathrm{CO}$-eq $/ \mathrm{kg}$ of CW, in East and South-East Asia (Gerber et al., 2013b). In those regions, there is a difference in emission intensity between beef produced from dairy herds and that from specialized beef herds. The emission intensity of beef from specialized beef herds is almost fourfold that produced from dairy herds (68 vs $18 \mathrm{~kg} \mathrm{CO}_{2}$-eq $/ \mathrm{kg}$ of $\mathrm{CW}$ ) because in specialized beef herds, the main production is meat, and all emissions are allocated to meat, while in dairy herds milk is the primary output and meat the secondary output, thus emissions are shared between the two outputs (Gerber et al., 2013b). The extensive beef management system uses large quantities of forage that increase gas emissions (Du Toit et al., 2013). In addition, the reproduction efficiency of cows in developing countries is low owing to nutrition and management problems, and this affects the emissions negatively. Furthermore, the health conditions of the animals play an important role because sick animals and animals affected by subclinical diseases have low production and thus the emissions per unit of product increases (Meissner et al., 2013a).

In a study conducted in Brazilian beef farms, $\mathrm{CH}_{4}$ from enteric fermentation was the most abundant source of gas, with $75 \%$ of total emissions when the meat cycle was analysed from cradle (in Brazil) to final market (Europe). At farm gate (not including emissions from land use changes) the emission intensity was 28 $\mathrm{kg} \mathrm{CO}$-eq $/ \mathrm{kg}$ of CW. The slaughter and transport of beef carcasses (free of bones where $1 \mathrm{~kg} \mathrm{CW}=0.7 \mathrm{~kg}$ bonefree CW) from Brazil to Europe (Stockholm) was $41 \mathrm{~kg} \mathrm{CO}$-eq $/ \mathrm{kg}$ bonefree $\mathrm{CW}$ (Cederberg et al., 2009). In Brazil, another study conducted in intensive farm systems with less than 2000 head per farm found emission intensity ranged from 4.8 to $8.2 \mathrm{~kg} \mathrm{CO}$-eq $/ \mathrm{kg}$ of live weight gain (from 9.0 to $15.5 \mathrm{~kg} \mathrm{CO}$-eq/ $/ \mathrm{kg}$ $\mathrm{CW}$ ), while for the farms with more than 2000 head the range was between 5.0 and $7.2 \mathrm{~kg} \mathrm{CO}$ eq $/ \mathrm{kg}$ of live weight gain (from 9.4 to $13.5 \mathrm{~kg} \mathrm{CO}$-eq/ $/ \mathrm{kg} \mathrm{CW}$ ). Values were low compared with the previous work owing to a partial lifecycle assessment, lack of consistency between boundaries, and differences in functional unit and time scale (Cerri et al., 2016). In Argentina, one of the large beef cattle countries, in which the majority of animals are raised on grass-based systems, $\mathrm{CH}_{4}$ emission intensity ranged from $37 \mathrm{~kg} \mathrm{CO}$-eq $/ \mathrm{kg} \mathrm{CW}$ (year 2008) to $40 \mathrm{~kg} \mathrm{CO}$-eq $/ \mathrm{kg} \mathrm{CW}$ (year 2010). The values were somewhat high compared with results from previous years owing to lower production efficiency caused by forage shortage in a long-lasting drought (Rearte \& Pordomingo, 2014).

\section{Buffalo}

Buffalo populations are present all over the world, but they are largely diffuse in developing countries in Asia and Africa, where the meat and milk play an important role in feeding the local populations (Wanapat \& Kang, 2013; Cawthorn \& Hoffman, 2014). Most buffalo milk (80\%) is produced in mixed systems in semiarid climates. Milk emission intensity was estimated at $3.2 \mathrm{~kg} \mathrm{CO}{ }_{2}-\mathrm{eq} / \mathrm{kg} \mathrm{FPCM}$ in South Asia, $3.7 \mathrm{~kg} \mathrm{CO} 2^{-}$ eq $/ \mathrm{kg}$ FPCM in Near East and North Africa, and $4.8 \mathrm{~kg} \mathrm{CO}$-eq $/ \mathrm{kg}$ FPCM in East and South-East Asia. Emission intensity of buffalo meat production has broad variations, ranging from $21 \mathrm{~kg} \mathrm{CO}$-eq/kg CW in Near East and North Africa to $70.2 \mathrm{~kg} \mathrm{CO}$-eq/ $/ \mathrm{kg} \mathrm{CW}$ in East and South-East Asia. The large variations are due to the quality of feed, different management systems and local climatic conditions (Gerber et al., 2013b). 
Table 1 Literature review of greenhouse gas emissions in developing countries ${ }^{a}$

\begin{tabular}{|c|c|c|c|c|}
\hline Species & $\begin{array}{l}\text { GHG emission in } \\
\text { kg CO}_{2}-\mathrm{eq}_{\mathrm{kg}-} \\
\text { product }^{-1}\end{array}$ & Developing country/region & $\begin{array}{l}\text { System } \\
\text { boundary }\end{array}$ & Reference \\
\hline \multirow[t]{4}{*}{$\begin{array}{l}\text { Dairy } \\
\text { cattle }\end{array}$} & $\begin{array}{l}7.5 \\
4.6 \\
3.7\end{array}$ & $\begin{array}{l}\text { Sub-Saharan Africa } \\
\text { North Africa } \\
\text { Near East }\end{array}$ & $\begin{array}{l}\text { Farm gate } \\
\text { Farm gate } \\
\text { Farm gate }\end{array}$ & \multirow{4}{*}{$\begin{array}{l}\text { Gerber et al., } 2010 \\
\text { Gerber et al., } 2010 \\
\text { Gerber et al., } 2010 \\
\text { Forabosco et al., } \\
\text { unpublished } \\
\text { Garg et al., } 2016 \\
\text { Weiler et al., } 2014 \\
\text { Garg et al., } 2014 \\
\text { Daneshi et al., } 2014\end{array}$} \\
\hline & 2.4 & Armenia & Farm gate & \\
\hline & $\begin{array}{l}2.2 \\
2.0 \\
1.8\end{array}$ & $\begin{array}{l}\text { India } \\
\text { Kenya } \\
\text { India }\end{array}$ & $\begin{array}{l}\text { Farm gate } \\
\text { Farm gate } \\
\text { Farm gate }\end{array}$ & \\
\hline & $1.73 \& 1.57$ & Iran & $\begin{array}{l}\text { Milk proc. Gate \& } \\
\text { Farm gate }\end{array}$ & \\
\hline Beef & 76 & South Asia & Farm gate & Gerber et al., 2013b \\
\hline \multirow[t]{5}{*}{ cattle } & 72 & Latina America and Caribbean & Farm gate & Gerber et al., 2013b \\
\hline & 71 & Sub-Saharan Africa & Farm gate & Gerber et al., 2013b \\
\hline & 69 & Brazil & $\begin{array}{l}\text { County of } \\
\text { destination }\end{array}$ & Cederberg et al., 2009 \\
\hline & 48 & East and South East Asia & Farm gate & \multirow{3}{*}{$\begin{array}{l}\text { Gerber et al., 2013b } \\
\text { Rearte \& Pordomingo, } \\
2014 \\
\text { Cederberg et al., 2009 } \\
\text { Opio et al., 2013 } \\
\text { Gerber et al., 2013b } \\
\text { Gerber et al., 2013b } \\
\text { Gerber et al., 2013b } \\
\text { Gerber et al., 2013b } \\
\text { Gerber et al., 2013b } \\
\text { Opio et al., 2013 } \\
\text { Garg et al., 2016 } \\
\text { Patra, 2012 }\end{array}$} \\
\hline & $37-40$ & Argentina & n.a. & \\
\hline $\begin{array}{l}\text { Buffalo } \\
\text { (milk) }\end{array}$ & $\begin{array}{l}28^{\mathrm{b}} \\
5.0-5.8 \\
4.8 \\
4.8 \\
3.7 \\
3.7 \\
3.2 \\
2.6-2.7 \\
2.5-3.0 \\
1.3-1.4\end{array}$ & $\begin{array}{l}\text { Brazil } \\
\text { North Africa } \\
\text { East Asia } \\
\text { South-East Asia } \\
\text { Near East } \\
\text { North Africa } \\
\text { South Asia } \\
\text { Near East } \\
\text { India } \\
\text { India }\end{array}$ & $\begin{array}{l}\text { Farm gate } \\
\text { Farm gate } \\
\text { Farm gate } \\
\text { Farm gate } \\
\text { Farm gate } \\
\text { Farm gate } \\
\text { Farm gate } \\
\text { Farm gate } \\
\text { Farm gate } \\
\text { n.a. }\end{array}$ & \\
\hline $\begin{array}{l}\text { Sheep } \\
\text { and }\end{array}$ & $29.0^{\mathrm{d}}$ & South Asia & Farm gate & Opio et al., 2013 \\
\hline goats & $\begin{array}{c}27.9^{\mathrm{d}} \\
25.5^{\mathrm{d}} \\
23.0^{\mathrm{d}} \\
19.0^{\mathrm{d}} \\
9.3-11.2^{\mathrm{c}} \\
8.9^{\mathrm{c}} \\
8.7^{\mathrm{c}} \\
6.9^{\mathrm{c}} \\
5.5-9.6^{\mathrm{c}} \\
4.9^{\mathrm{c}}\end{array}$ & $\begin{array}{l}\text { Near East and North Africa } \\
\text { Latin America } \\
\text { East and Southeast Asia } \\
\text { New Zealand } \\
\text { Near East and North Africa } \\
\text { East and South-East Asia } \\
\text { Near East and North Africa } \\
\text { Sub-Saharan Africa } \\
\text { Latin America and Caribbean } \\
\text { South Asia }\end{array}$ & $\begin{array}{l}\text { Farm gate } \\
\text { Farm gate } \\
\text { Farm gate } \\
\text { Farm gate } \\
\text { Farm gate } \\
\text { Farm gate } \\
\text { Farm gate } \\
\text { Farm gate } \\
\text { Farm gate } \\
\text { Farm gate }\end{array}$ & $\begin{array}{l}\text { Opio et al., } 2013 \\
\text { Opio et al., } 2013 \\
\text { Opio et al., } 2013 \\
\text { Ledgard et al., } 2011 \\
\text { Opio et al., 2013 } \\
\text { Gerber et al., 2013b } \\
\text { Gerber et al., 2013b } \\
\text { Gerber et al., 2013b } \\
\text { Opio et al., 2013 } \\
\text { Gerber et al., 2013b }\end{array}$ \\
\hline Pigs & $\begin{array}{l}6.0-7.1 \\
6.0-6.7 \\
5.8-6.8 \\
5.5-6.9\end{array}$ & $\begin{array}{l}\text { Developing regions } \\
\text { China } \\
\text { Vietnam } \\
\text { Developing regions }\end{array}$ & $\begin{array}{l}\text { Farm gate } \\
\text { Farm gate } \\
\text { Farm gate } \\
\text { Farm gate }\end{array}$ & $\begin{array}{l}\text { Gerber et al., 2013b } \\
\text { Mottet et al., } 2017 \\
\text { Macleod et al., } 2013 \\
\text { Macleod et al., } 2013\end{array}$ \\
\hline Chicken & $\begin{array}{c}6.2^{\mathrm{e}} \\
5.0^{\mathrm{e}} \\
3.5^{\mathrm{e}} \\
3.2^{\mathrm{e}} \\
2.7^{\mathrm{e}} \& 6.2^{\mathrm{d}}\end{array}$ & $\begin{array}{l}\text { East and South-East Asia } \\
\text { Sub-Saharan Africa } \\
\text { Near East and North Africa } \\
\text { Latin America and the Caribbean } \\
\text { South Asia } \\
\text { East and South-East Asia, Near East and }\end{array}$ & $\begin{array}{l}\text { Farm gate } \\
\text { Farm gate } \\
\text { Farm gate } \\
\text { Farm gate } \\
\text { Farm gate }\end{array}$ & $\begin{array}{l}\text { Gerber et al., 2013b } \\
\text { Gerber et al., 2013b } \\
\text { Gerber et al., 2013b } \\
\text { Gerber et al., 2013b } \\
\text { Gerber et al., 2013b }\end{array}$ \\
\hline & $5.8^{d}$ & North Africa & Farm gate & Gerber et al., 2013b \\
\hline
\end{tabular}


In the same region, Opio et al. (2013) found broad variations in emission intensities. In mixed dairy buffalo systems in arid zones in Near East and North Africa, emissions can vary between 2.6 and $5.8 \mathrm{~kg}$ $\mathrm{CO}_{2}$-eq/kgFPCM, respectively. In the same region and agro-ecological zone, but in a different system (grassland dairy buffalo system), emissions can vary between 2.7 and $5.0 \mathrm{~kg} \mathrm{CO}{ }_{2}$-eq $/ \mathrm{kg}$ of FPCM. A lifecycle assessment (cradle to farm gate) in India estimated that the emissions from buffalo milk ranged from 2.5 to $3.0 \mathrm{~kg} \mathrm{CO}$-eq $/ \mathrm{kg}$ of FPCM, and that the contribution of $\mathrm{CH}_{4}$ and $\mathrm{N}_{2} \mathrm{O}$ on emission from buffalos accounted for $80.5 \%$ and $11.3 \%$, respectively, of total farm emissions (Garg et al., 2016). Similar results were confirmed by (Garg et al., 2014)for buffalo in India, where the enteric and manure emissions of $\mathrm{CH}_{4}$ and manure management emission of $\mathrm{N}_{2} \mathrm{O}$ were $71.6 \%, 7.4 \%$, and $12.6 \%$, respectively. Patra (2012), in a study of dairy buffalos in the same country using 2003 and 2007 data, estimated the emissions to be equal to 1.4 and 1.3 $\mathrm{kg} \mathrm{CO}$-eq/kg FPCM, respectively. In a different study in India, Chhabra et al. (2013) found that buffalo had a lower contribution of enteric $\mathrm{CH}_{4}$ emission, which was $42 \%$ of total enteric emission, and the $\mathrm{CH}_{4}$ emission from manure management accounted for $9.3 \%$ of the total livestock $\mathrm{CH}_{4}$ emissions. Chhabra et al. (2013) found total $\mathrm{CH}_{4}$ emission from buffalo in India of $51.3 \%$, lower than the value found by Garg et al. (2014) and Garg et al. (2016), but differences are due mainly to differences in the datasets.

\section{Sheep and goats}

Small ruminants in developing countries represent an important economic resource for local communities (Tindano et al., 2015; Yogi et al., 2015). In the regions where large populations of sheep and goats are raised in East and South-East Asia, Near East and North Africa, sub-Saharan Africa and South Asia, emission intensities for milk are 8.9, 8.7, 6.9, and $4.9 \mathrm{~kg} \mathrm{CO}$-eq/ $/ \mathrm{kg} \mathrm{FPCM}$, respectively (Gerber et al., 2013b). South Asia showed the lowest emission intensity in developing regions because the productivity of small ruminants is relatively high compared with other regions. Goat milk tends to have lower emission intensity compared with sheep milk in the same developing region owing to its high productivity. Large differences in emission can be observed in developing regions in relation to different agro-ecological zones and systems. For example, in arid zones of Near East and North Africa, emission intensity can range between 9.3 and $11.2 \mathrm{~kg} \mathrm{CO}$-eq $/ \mathrm{kg} \mathrm{FPCM}$ in grassland and mixed systems, respectively. In humid regions of Latin America and the Caribbean, the variations between systems are even larger $\left(9.6\right.$ and $5.5 \mathrm{~kg} \mathrm{CO}$ - $^{-}$ eq/kg FPCM in grassland and mixed systems, respectively) and are caused by differences in feed quality and productivity of the animals (Opio et al., 2013). In West Africa, Gerber et al. (2013b) and Mottet et al. (2016) found for milk produced by small ruminants an emission intensity of $8.2 \mathrm{~kg} \mathrm{CO}$-eq/kg FPCM, which is $20 \%$ higher than the global average of $6.8 \mathrm{~kg} \mathrm{CO}_{2}$-eq $/ \mathrm{kg}$ FPCM. This phenomenon can be related to low productivity owing to lower feed digestibility (average feed digestibility of $55 \%$, in comparison with the global average of $59 \%$ ), poor animal health (mortality rates for adult and young animals were $9.5 \%$ and $26 \%$, respectively, compared with global average rates of $8.8 \%$ and $20.6 \%$, respectively), and poor breeding (absence of selection plans). Emission intensity of meat from small ruminants has small variations among developing regions of the world. In East and South-East Asia, Latin America, Near East and North Africa, and South Asia, intensities are 23.0, 25.5, 27.9, and $29.0 \mathrm{~kg} \mathrm{CO}$-eq/ $\mathrm{kg} \mathrm{CW}$, respectively (Opio et al., 2013). In a lifecycle assessment of lamb meat for export in New Zealand, Ledgard et al. (2011) found an average emission intensity of $19 \mathrm{~kg} \mathrm{CO}_{2}$-eq $/ \mathrm{kg}$ of lamb meat. In this investigation, the authors found that $80 \%$ of the emissions are produced within the farm (mainly $\mathrm{CH}_{4}$ and $\mathrm{N}_{2} \mathrm{O}$ ), $3 \%$ from processing, $5 \%$ from transportation and $12 \%$ from retail and home cooking.

\section{Pigs}

At global level, over half of total $\mathrm{CH}_{4}$ emissions are from non-ruminants, and pigs play a fundamental role (O'Mara, 2011). In 2010, pig emissions were about the same in developed and developing countries., In 1992-2010 pig emissions in transition economies declined by $4.4 \%$ per year (Caro et al., 2014). In developing regions, emission intensity was greater, and ranged between 6.0 and $7.1 \mathrm{~kg} \mathrm{CO}$-eq/kg CW. Latin American and Caribbean regions had the highest emission with $7.1 \mathrm{~kg} \mathrm{CO}$-eq/ $/ \mathrm{kg} \mathrm{CW}$, followed by East and South-East Asia, with $6.0 \mathrm{~kg} \mathrm{CO}$-eq/ $/ \mathrm{kg} \mathrm{CW}$. Large differences could be found among production systems, and the backyard system had the lowest emissions compared with industrialized and intermediate systems. However, the backyard system is characterized by relatively high manure emissions $\left(\mathrm{CH}_{4}\right.$ and $\left.\mathrm{N}_{2} \mathrm{O}\right)$ caused by low-quality feed (Gerber et al., 2013b). The results were confirmed by Macleod et al. (2013), who found in developing regions less emission intensity $\left(5.5-6.9 \mathrm{~kg} \mathrm{CO}_{2}-\mathrm{eq} / \mathrm{kg} \mathrm{CW}\right)$ for the backyard system than for the intermediate and industry systems. In China, animal farming is a significant source of GHG emissions into the atmosphere owing to the large number of pigs and the great emissions of $\mathrm{NH}_{3}$ (ammonia) and $\mathrm{N}_{2} \mathrm{O}$ in the environment (Gao et al., 2013). In a different study, Mottet et al. (2016) pointed out that pig production has increased in China in the last three decades, mostly in the intermediate and industrial systems, and now 
accounts for $30 \%$ and $40 \%$ of total production, respectively, of the entire east and southeast region. The authors estimated that the emission intensity was $6.7 \mathrm{~kg} \mathrm{CO}$-eq/kg CW for intermediate pig production systems and $6.0 \mathrm{~kg} \mathrm{CO}$-eq/kg CW for industrial pig production systems. In Vietnam, using a Monte Carlo analysis, the intensity of emissions for backyard and intermediate systems for pigs was estimated at 6.8 and $5.8 \mathrm{~kg} \mathrm{CO}_{2}$-eq/kg CW, respectively, and results were similar to previous studies (Macleod et al., 2013).

\section{Chicken}

Poultry contributes significantly to manure management emissions, which drive increases in $\mathrm{N}_{2} \mathrm{O}$ emissions because of the relatively high nitrogen content of poultry waste and the manure management systems (EPA, 2011). In developing countries there are three types of chicken production systems: backyard layers, industrial layers (both are for meat and eggs), and industrial broilers (only meat). The most common system in marginal and poor areas of non-industrialized countries is the backyard system (Sarwar et al., 2015), which is characterized by high emission intensity caused by poor feed conversion ratios, high proportion of unproductive animals, high mortality and low fertility rates (Gerber et al., 2013b). Chickens for meat production in general have high emission intensity compared with egg production, because more feed is required to produce $1 \mathrm{~kg}$ meat compared with $1 \mathrm{~kg}$ eggs. The emission intensity of chicken egg production in developing regions was $6.2 \mathrm{~kg} \mathrm{CO}$-eq $/ \mathrm{kg}$ eggs in East and South-East Asia, $5 \mathrm{~kg} \mathrm{CO}$-eq $/ \mathrm{kg}$ eggs in subSaharan Africa, $3.5 \mathrm{~kg} \mathrm{CO}$-eq/ $/ \mathrm{kg}$ eggs in Near East and North Africa, $3.2 \mathrm{~kg} \mathrm{CO}$-eq/ $/ \mathrm{kg}$ of eggs in Latin America and the Caribbean, and $2.7 \mathrm{~kg} \mathrm{CO}$-eq $/ \mathrm{kg}$ eggs in South Asia. The highest value of emissions in East and South-East Asia were caused mainly by moderate feed emission intensity and high anaerobic activity of manure storage (Macleod et al., 2013). For chicken meat production, Garber et al. (2013a) found a small variation among developing regions with an average emission intensity ranging from $6.2 \mathrm{~kg} \mathrm{CO}$-eq/ $\mathrm{kg}$ of $\mathrm{CW}$ in South Asia to $5.8 \mathrm{~kg} \mathrm{CO}$-eq/kg of $\mathrm{CW}$ in East and South-East Asia, Near East and North Africa. The range of emissions among developing regions is therefore very close, indicating that production systems and the level of technology are at similar levels. In India, it was estimated that the total $\mathrm{N}_{2} \mathrm{O}$ emission of Indian livestock in 2003 was equal to $1.42 \mathrm{Gg} /$ year. The major contribution of $\mathrm{N}_{2} \mathrm{O}$, at $86.1 \%$, was from poultry, while the contribution of $\mathrm{CH}_{4}$ was marginal (Chhabra et al., 2013).

\section{Methane and nitrous oxide mitigation strategies from a livestock prospective}

The main aim of $\mathrm{CH}_{4}$ and $\mathrm{N}_{2} \mathrm{O}$ mitigation strategies involves actions that limit the magnitude of negative long-term effects of climate change. Mitigation generally involves reductions in livestock emissions (e.g. respiration and manure) and anthropogenic emissions linked with livestock activities (e.g. fodder production, crop processing, and manure distribution). Mitigation may also be achieved by increasing the capacity of carbon sinks, (e.g. through restoration of degraded soils, and reforestation) and through correct long-term sustainable policies that reduce the risks associated with human-induced global warming. However, mitigation strategies in developed countries are not always feasible and economically sustainable for developing countries. In this section, the authors discuss sustainable mitigation strategies for the reduction of $\mathrm{CH}_{4}$ and $\mathrm{N}_{2} \mathrm{O}$ emissions in livestock focusing on three areas: selection, feeding, and management.

\section{Selection}

In developing countries, measuring $\mathrm{CH}_{4}$ and $\mathrm{N}_{2} \mathrm{O}$ emissions directly from animals is not always feasible owing to high costs and the need for expensive infrastructure such as respiration chambers. In future, when the costs of genomic selection will be more affordable for breeding organizations in transition economies, it may be possible to genotype breeding animals and estimate genomic breeding values for $\mathrm{CH}_{4}$ and $\mathrm{N}_{2} \mathrm{O}$ emissions. In industrialized countries, genomic selection is a reality (Hayes et al., 2013; Pickering et al., 2015a; Pickering et al., 2015b; Meuwissen et al., 2016), but in developing countries it is not yet disseminated (Scholtz et al., 2010). One of the major issues is the costs associated with the measurement of $\mathrm{CH}_{4}$ and $\mathrm{N}_{2} \mathrm{O}$ emissions and genotyping of a large sample of animals (reference population). The great advantage of this method is that when the equations that predict genomic breeding values from SNPs (single nucleotide polymorphisms) are estimated on the reference population, they can then be used to predict genomic breeding values (GBV) for selection candidates based on their genotypes alone without the need to collect phenotypic data and with good accuracy of GBV (Calus et al., 2013). Alternatively, when direct measures of $\mathrm{CH}_{4}$ and $\mathrm{N}_{2} \mathrm{O}$ cannot feasibly be applied to enough animals to establish a reference population, genomic selection can be based on correlated traits such as dry matter intake and other proxies. While there is evidence that there are correlated and predictor traits for $\mathrm{CH}_{4}$ and $\mathrm{N}_{2} \mathrm{O}$ emissions, the current level of knowledge is insufficient to recommend their use in selection to reduce these gases (Pickering et al., 2015b). In developing countries, where genetic selection is already in place, $\mathrm{CH}_{4}$ emission from enteric fermentation could be reduced by including in the total merit index (TMI) traits that reduce mortality (such as fertility, 
longevity, and animal health) and increase the number of productive animals (Meissner et al., 2013a). More fertile females, healthy, and with good longevity, can have more offspring. Thus, their feed requirements and gas emissions are diluted over this increased number of offspring. Furthermore, in those countries where protein for human consumption is a priority and productivity of animals is low, selection to increase the quantity of product per animal (e.g. meat, milk, eggs, and wool) should be maintained. Eventually the weight of this trait in the TMI should be increased. With the increase of productivity per animal, total $\mathrm{CH}_{4}$ and $\mathrm{N}_{2} \mathrm{O}$ emissions may increase, but emission intensity would be reduced, because the total emissions would be diluted over an increased quantity of product. Genetic improvement of indirect traits, such as feed conversion efficiency, plays an important role in the reduction of emissions for all livestock species, and is particularly important in swine and chicken. Those species have little contribution to enteric $\mathrm{CH}_{4}$ emission as most $\mathrm{CH}_{4}$ and $\mathrm{N}_{2} \mathrm{O}$ are caused by manure storage and land application. Thus, genetic improvement of feed conversion efficiency reduces the total manure produced and consequently reduces the emissions of $\mathrm{CH}_{4}$ and $\mathrm{N}_{2} \mathrm{O}$ while maintaining productivity (Hristov et al., 2013a). In dairy and beef cattle, genetic selection for residual feed intake has shown that this indirect approach to reducing $\mathrm{CH}_{4}$ emission is moderately heritable (0.26 to 0.43$)$ and moderately repeatable across diets $(0.33$ to 0.67$)$, indicating that the inclusion of this trait in the TMI could effectively reduce $\mathrm{CH}_{4}$ emissions (Basarab et al., 2013). In developing countries, where economic resources for selection are insufficient, $\mathrm{CH}_{4}$ and $\mathrm{N}_{2} \mathrm{O}$ emission reduction from enteric and manure fermentation can be achieved with the financial support of international donors (Arakelyan \& Moran, 2015; Samaniego \& Schneider, 2015) and with the aggregation of countries that have similar selection interests. Aggregation of countries could reduce selection costs per country, increase the number of potential candidates, select for animals that have high performance (i.e., high productivity, low mortality rate, better health), and generate profit with the commercialization of genetic material (i.e. offspring, semen and embryos) of superior animals. Furthermore, the use of local genetic resources in poor countries with extreme environmental conditions (i.e. hot or harsh environments) represents a better solution than importing highly improved animals that cannot perform as expected because of environmental constraints (Boettcher et al., 2015). On the opposite side, for developing countries with an environment similar to Europe and North America, the use of exotic breeds (European and American) instead of local genetic resources could represent an efficient economic solution (Kavoi et al., 2010) and have a positive effect on reducing GHG emissions (Mushi et al., 2015). In intermediate climate conditions, such as South Africa, crossbreeding could be a sustainable solution to mitigating gas emission (Scholtz et al., 2012; Mokolobate et al., 2014). In this country, $67 \%$ of feedlot cattle are crossbreeds from indigenous Sanga and exotic breeds aimed at increasing meat production and adaptability and reducing $\mathrm{CH}_{4}$ emissions. The use of two-breed and three-breed crosses of indigenous and exotic breeds increases productivity owing to the heterosis effect and reduces the $\mathrm{CH}_{4}$ emission per unit of product (Scholtz et al., 2013b). However, it is important to ensure that the indigenous breeds are properly conserved (Boettcher et al., 2015) to guarantee the availability of purebred animals and provide sustainable food for local populations (Meissner et al., 2013b; Rust \& Rust, 2013). In India and other developing countries, where, for religious reasons, cattle are not slaughtered, if available, the use of sexed semen could be a sustainable solution to reducing the number of unproductive cattle, and this technology could have the positive effect of reducing $\mathrm{CH}_{4}$ and $\mathrm{N}_{2} \mathrm{O}$ emissions (Hristov et al., 2013b). In developing countries, where genetically modified animals (GMA) are authorized, the use of environmentally friendly GMA is an option that should be investigated (Forabosco et al., 2013).

\section{Feeding}

In developing countries, an important mitigation option for livestock, in particular ruminants, is the utilization of forages of higher digestibility. This aspect is particularly important in those countries where the digestibility of forages in general is limited owing to high amounts of lignin because of incorrect management of agronomical practices. When the digestibility of forages increases, enteric fermentation and manure production are reduced, and consequently the emissions of $\mathrm{CH}_{4}$ and $\mathrm{N}_{2} \mathrm{O}$ decrease. For example, when legume silage replaces grass silage in the diet, because of the lower fibre content and the presence of high digestible organic nitrogen, $\mathrm{CH}_{4}$ and $\mathrm{N}_{2} \mathrm{O}$ emissions are reduced (Hristov et al., 2013a). Smallholders in mixed crop livestock systems in Africa and Asia are characterized by livestock herds with many unproductive animals, small quantities of high-quality feed and large quantities of low-quality feed. An effective mitigation strategy is to reduce the number of animals (keeping only the best animals) and provide feed with higher digestibility, reserving the low-quality feed for other purposes (e.g. bedding). This strategy would increase productivity and reduce $\mathrm{CH}_{4}$ and $\mathrm{N}_{2} \mathrm{O}$ emissions. However, this mitigation option is in conflict with the interests of smallholders, who want to have large unproductive herds for social and risk mitigation reasons. Regulatory measures (policy and quota systems), economic incentives (micro credits and loans in kind), and change in social behaviours (social disincentives) could reduce the benefits of keeping unproductive animals 
and support the intensification of livestock production (Udo et al., 2011; Haileslassie et al., 2016). In a study in India, important mitigation measures for livestock are improving feed by adding digesters and $\mathrm{CH}_{4}$ inhibitors and enhancing the number of crossbred animals that have lower $\mathrm{CH}_{4}$ emissions per unit of production (Garg et al., 2011). In poor economies, urea is used extensively to improve low-quality feed. It is mixed with fodder (e.g. straws and crop residuals) at least one week prior to use. During this period ammonia is formed, which breaks the cell walls and allows the microorganisms in the rumen to metabolize the organic material in the cells, improving feed intake and digestibility. In addition, urea provides $\mathrm{N}$, which improves the feed value (Dawit et al., 2015). A good mitigation option, but less feasible in developing countries, is the use of concentrate feeds in the animal's diet. Concentrates are rich in lipids (oils) and other substances with high levels of energy (e.g. cereal grains). The inclusion of concentrate feeds in the diet of ruminants and nonruminants could reduce $\mathrm{CH}_{4}$ emission intensity (Herrero et al., 2016), but the possibility of using this mitigation tool in poor economies depends on costs and availability. Forage processing, such as the mechanical reduction in size of forages, increases digestibility, feed intake and animal productivity, and could be considered an effective enteric $\mathrm{CH}_{4}$ mitigation practice in poor economies (Makkar, 2016). Correct pasture management, crop rotation and an intensive grazing system could be important mitigation practices that could guarantee more efficient conversion of forage into economic products and result in $\mathrm{CH}_{4}$ and $\mathrm{N}_{2} \mathrm{O}$ emission reduction (Gerber et al., 2013a; Havlík et al., 2014). Other technical mitigation options (Gerber et al., 2013a; Erasmus \& Webb, 2014; Herrero et al., 2016; Elghandour et al., 2016), such as the use of feed additives (electron receptors, ionophore antibiotics, enzymes and probiotics), vaccines and precision feeding, are not available or only partially available in marginal economies. Their availability and use are limited because of high costs, limited accessibility, policy limitations, lack of technology, and lack of breeders' specific knowledge.

\section{Management of manure}

In developing countries, manure and slurry are not always considered valuable resources, and unmanaged accumulation of animal waste represents a source of gas emissions and a health threat for animals and humans. Unmanaged manure and slurry can cause eutrophication and contamination of surface water, leaching of nitrates, degradation of natural resources and $\mathrm{GHG}$ in the form of $\mathrm{CH}_{4}$ and $\mathrm{N}_{2} \mathrm{O}$ (direct and indirect emissions), $\mathrm{NH}_{3}$, and other toxic gases (Hristov et al., 2013a). In Africa, the management of manure depends largely on the livestock management system: in the extensive rangeland system, manure is not managed, while in the mixed system, manure is applied only partially to grazing land, and in the industrial system it is applied mainly to high-value crops such as coffee, tea, and tobacco (Herrero et al., 2013). Furthermore, in both extensive and intensive grazing systems, where $\mathrm{N}$ concentrations per hectare are high, large $\mathrm{N}$ losses occur through leaching and volatilization from point sources of urine and solid manure (Petersen et al., 2013). In Asia, manure is considered a valuable resource, and is used as organic fertilizer, in biogas production, and as biofuel. In Latin America, recycling of manure is not diffuse owing to availability of cheap industrial fertilizer, deforestation and subsequent expansion of agriculture on fertile land, and a rotation system with the possibility of letting the soil regenerate for a few years (Thien Thu et al., 2012; Herrero et al., 2013). Large differences in manure management can be seen between countries in the same continent. This depends mainly on the farmers' knowledge, financial state support (for biogas production, construction of modern lagoons for slurry, machineries for the distribution of manure, etc.) and national policies (Jiang et al., 2011; Teenstra et al., 2014). Correct management of manure has been extensively demonstrated to be the most important tool that can minimize losses due to $\mathrm{CH}_{4}$ and $\mathrm{N}_{2} \mathrm{O}$ volatilization and runoff (Petersen et al., 2013; Sommer et al., 2013). Manure from ruminants and non-ruminants can be treated by various methods for improved handling, nutrient use and energy generation. In developing countries, simple techniques such as piling, compacting and covering the manure have positive effects on reducing emissions and nutrient losses. For example, covering solid manure with straw or plastic sheets reduces, in general, both $\mathrm{CH}_{4}$ and $\mathrm{N}_{2} \mathrm{O}$ emissions, whereas covering liquid manure stores is adopted mainly to reduce $\mathrm{NH}_{3}$ emissions (Petersen et al., 2013). $\mathrm{N}_{2} \mathrm{O}$ emissions from liquid slurry are minimal during storage, unless a surface crust is present (VanderZaag et al., 2009). In sub-Saharan Africa, the production of compost in pits with a mix of animal faeces, feed and crop residues and domestic waste is extensively prevalent among small households. Householders irrigate the pit, turn the compost, use a cover to limit $\mathrm{N}$ losses, and use the compost as natural fertilizer, because it is particularly rich in nutrients (Smith et al., 2014). In Vietnam, parts of both liquid and solid manure produced by pig farms are applied to fish ponds and used to feed fish for local consumption (Vu et al., 2012). Modern technology, such as manure separation, anaerobic digestion, aeration, use of additives and inhibitors (Petersen et al., 2012; Zaman \& Nguyen, 2012; Gebrezgabher et al., 2015; Kinyua et al., 2016), to treat manure and slurry from ruminates and nonruminants, may not represent a feasible option to reduce GHG emissions in developing countries. The main 
reasons are high costs, low accessibility, high technology required, lack of knowledge, and insufficient legislation.

\section{Conclusions}

This review investigated $\mathrm{CH}_{4}$ and $\mathrm{N}_{2} \mathrm{O}$ emissions from livestock and mitigation actions in developing countries. The results indicate that emission intensities from livestock are medium to high in poor countries owing to low animal productivity, low feed quality, lack of knowledge, and limited investments. There are differences among developing countries in animal gas emissions in the same continent or region, indicating that improvements are possible. The countries with lowest livestock gas emissions should be the drivers of improvement of all other countries in the same region or continent. Developing countries should promote production systems with low emission intensity (chicken meat, eggs, cow milk and pork meat) or medium emission intensity (meat and milk from small ruminants), and the international community should support modernizing and improving the efficiency of productions with the higher emission intensity (meat from beef cattle). Mitigation tools to reduce $\mathrm{CH}_{4}$ and $\mathrm{N}_{2} \mathrm{O}$ emissions that are used in industrialized countries are not always applicable to developing countries. Developing countries must use the mitigation tools adaptable to their conditions, considering the costs, knowledge, applicability, and local legislation. In the future, interdisciplinary research should focus on the integration of livestock emissions at country level and sustainable mitigation and adaptation tools that could be applied at local levels.

\section{Acknowledgements}

This work was carried out with the support of grant n 2884 2015.VII.4.3, DAFNAE, University of Padova, Italy.

\section{Authors' Contributions}

FF designed the study, wrote the manuscript and reviewed the manuscript critically for important climate change issues. ZC carried out the manuscript writing, and RR drafted and reviewed the manuscript critically for important livestock issues and gave the final approval of the version for publishing.

\section{Conflict of Interest Declaration}

The authors declare that they have no affiliations with any organisation or entity with any financial or non-financial interest that could bias the subject matter and outcomes discussed in this manuscript.

\section{References}

Alexandratos, N. \& Bruinsma, J., 2012. World agriculture towards 2015/2030: The 2012 Revision. ESA Work. Pap. No. $12,1-147$.

Aluwong, T., Wuyep, P.A. \& Allam, L., 2011. Livestock-environment interactions: Methane emissions from ruminants. Afr. J. Biotechnol. 10, 1265-1269.

Arakelyan, I. \& Moran, D., 2015. Nationally appropriate mitigation actions for the dairy sector in Malawi: needs and opportunities (W Leal Filho, ed.). Springer Berlin Heidelberg.

Basarab, J.A., Beauchemin, K.A., Baron, V.S., Ominski, K.H., Guan, L.L., Miller, S.P. \& Crowley, J.J., 2013. Reducing GHG emissions through genetic improvement for feed efficiency: effects on economically important traits and enteric methane production. Animal 7, 303-315.

Bhatta, R., Malik, P., Prasad, C. \& Bhatta, R., 2015. Enteric methane emission: status, mitigation and future challenges: an Indian perspective. Livest. Prod. Clim. Chang. 6, 229-244.

Boettcher, P.J., Hoffmann, I., Baumung, R., Drucker, A.G., McManus, C., Berg, P., Stella, A., Nilsen, L., Moran, D., Naves, M. \& Thompson, M., 2015. Genetic resources and genomics for adaptation of livestock to climate change. Front. Genet. 5, 1-3.

Calus, M.P.L., De Haas, Y., Pszczola, M. \& Veerkamp, R.F., 2013. Predicted accuracy of and response to genomic selection for new traits in dairy cattle. Anim. Anim. Consort. 7, 183-191.

Caro, D., Davis, S.J., Bastianoni, S. \& Caldeira, K., 2014. Global and regional trends in greenhouse gas emissions from livestock. Clim. Change 126, 203-216.

Cawthorn, D.-M. \& Hoffman, L.C., 2014. The role of traditional and non-traditional meat animals in feeding a growing and evolving world. Anim. Front. 4, 6-12.

Cederberg, C., Meyer, D. \& Flysjö, A., 2009. Life cycle inventory of greenhouse gas emissions and use of land and energy in Brazilian beef production. SIK-Institutet för Livsmed. och Biotek. 792, 5-67.

Cerri, C.C., Moreira, C.S., Alves, P.A., Raucci, G.S., Castigioni, B.D.A., Mello, F.F.C., Cerri, D.G.P. \& Cerri, C.E.P., 2016. Assessing the carbon footprint of beef cattle in Brazil: A case study with 22 farms in the State of Mato Grosso. J. Clean. Prod. 112, 2593-2600.

Chadwick, D., Sommer, S., Thorman, R., Fangueiro, D., Cardenas, L., Amon, B. \& Misselbrook, T., 2011., Manure management: Implications for greenhouse gas emissions. Anim. Feed Sci. Technol. 166-167, 514-531.

Chhabra, A., Manjunath, K.R., Panigrahy, S. \& Parihar, J.S., 2013. Greenhouse gas emissions from Indian livestock. Clim. Change 117, 329-344. 
Daneshi, A., Esmaili-Sari, A., Daneshi, M. \& Baumann, H., 2014. Greenhouse gas emissions of packaged fluid milk production in Tehran. J. Clean. Prod. 80, 150-158.

Dawit, A., Teklu, W., Birhanu, T. \& Aliye, K., 2015. Participatory evaluation and demonstration of urea treatment of straws in Sinana districts of Bale highlands Southeastern Ethiopia. Sci. J. Crop Sci. 4, 54-59.

Du Toit, C.J.L., Meissner, H.H. \& van Niekerk, W.A., 2013. Direct methane and nitrous oxide emissions of South African dairy and beef cattle. S. Afr. J. Anim. Sci. 43, 320-339.

Elghandour, M.M.Y., Kholif, A.E., Salem, A.Z.M., Montes de Oca, R., Barbabosa, A., Mariezcurrena, M. \& Olafadehan, O.A., 2016. Addressing sustainable ruminal methane and carbon dioxide emissions of soybean hulls by organic acid salts. J. Clean. Prod. 135, 194-200.

EPA. 2011. Global Anthropogenic Non-CO 2 Greenhouse Gas Emissions: 1990 - 2030. Washington D.C., U.S.A.

Erasmus, L.J. \& Webb, E.C., 2014. The effect of production system and management practices on the environmental impact, quality and safety of milk and dairy products. S. Afr. J. Anim. Sci. 43, 424-434.

Forabosco, F., Löhmus, M., Rydhmer, L. \& Sundström, L.F., 2013. Genetically modified farm animals and fish in agriculture: A review. Livest. Sci. 153, 1-9.

Gao, Z., Ma, W., Zhu, G. \& Roelcke, M., 2013. Estimating farm-gate ammonia emissions from major animal production systems in China. Atmos. Environ. 79, 20-28.

Garg, A., Kankal, B. \& Shukla, P.R., 2011. Methane emissions in India: Sub-regional and sectoral trends. Atmos. Environ. 45, 4922-4929.

Garg, M.R., Phondba, B.T., Sherasia, P.L. \& Makkar, H.P.S., 2016. Carbon footprint of milk production under smallholder dairying in Anand district of Western India: A cradle-to-farm gate life cycle assessment. Anim. Prod. Sci. 56, 423436.

Garg, M.R., Sherasia, P.L., Phondba, B.T. \& Makkar, H.P.S., 2014. Greenhouse gas emission intensity based on lifetime milk production of dairy animals, as affected by ration-balancing program. Anim. Prod. Sci.

Gebrezgabher, S.A., Meuwissen, M.P.M., Kruseman, G., Lakner, D. \& Oude Lansink, A.G.J.M., 2015. Factors influencing adoption of manure separation technology in the Netherlands. J. Environ. Manage. 150, 1-8.

Gerber, P.J., Vellinga, T., Opio, C., Henderson, B. \& Steinfeld, H., 2010. Greenhouse gas emissions from the dairy sector. A life cycle assessment. Africa S 1, 1-94.

Gerber, P.J., Vellinga, T., Opio, C. \& Steinfeld, H., 2011. Productivity gains and greenhouse gas emissions intensity in dairy systems. Livest. Sci. 139, 100-108.

Gerber, P.J., Steinfeld, H., Henderson, B., Mottet, A., Opio, C., Dijkman, J., Falculli, A. \& Tempio, G., 2013b. Tackling climate change through livestock: A global assessment of emissions and mitigation opportunities. Food and Agriculture Organization of the United Nations, Rome.

Gerber, P.J., Hristov, A.N., Henderson, B., Makkar, H., Oh, J., Lee, C., Meinen, R., Montes, F., Ott, T., Firkins, J., Rotz, A., Dell, C., Adesogan, A.T., Yang, W.Z., Tricarico, J.M., Kebreab, E., Waghorn, G., Dijkstra, J. \& Oosting, S., 2013a. Technical options for the mitigation of direct methane and nitrous oxide emissions from livestock: a review. Animal 7:s2, 220-234.

Haileslassie, A., Craufurd, P., Thiagarajah, R., Kumar, S., Whitbread, A., Rathor, A., Blummel, M., Ericsson, P. \& Kakumanu, K.R., 2016. Empirical evaluation of sustainability of divergent farms in the dryland farming systems of India. Ecol. Indic. 60, 710-723.

Havlík, P., Valin, H., Herrero, M., Obersteiner, M., Schmid, E., Rufino, M.C., Mosnier, A., Thornton, P.K., Böttcher, H., Conant, R.T., Frank, S., Fritz, S., Fuss, S., Kraxner, F. \& Notenbaert, A., 2014. Climate change mitigation through livestock system transitions. Proc. Natl. Acad. Sci. U. S. A. 111, 3709-14.

Hayes, B.J., Lewin, H.A. \& Goddard, M.E., 2013. The future of livestock breeding: Genomic selection for efficiency, reduced emissions intensity, and adaptation. Trends Genet. 29, 206-214.

Herrero, M., Thornton, P.K., Kruska, R. \& Reid, R.S., 2008. Systems dynamics and the spatial distribution of methane emissions from African domestic ruminants to 2030. Agric. Ecosyst. Environ. 126, 122-137.

Herrero, M., Grace, D., Njuki, J., Johnson, N., Enahoro, D., Silvestri, S. \& Rufino, M.C., 2013. The roles of livestock in developing countries. Animal 7, 3-18.

Herrero, M., Gerber, P., Vellinga, T., Garnett, T., Leip, A., Opio, C., Westhoek, H.J., Thornton, P.K., Olesen, J., Hutchings, N., Montgomery, H., Soussana, J.F., Steinfeld, H. \& McAllister, T.A., 2011. Livestock and greenhouse gas emissions: The importance of getting the numbers right. Anim. Feed Sci. Technol. 166-167, 779-782.

Herrero, M., Henderson, B., Havlík, P., Thornton, P.K., Conant, R.T., Smith, P., Wirsenius, S., Hristov, A.N., Gerber, P., Gill, M., Butterbach-Bahl, K., Valin, H., Garnett, T. \& Stehfest, E., 2016. Greenhouse gas mitigation potentials in the livestock sector. Nat. Clim. Chang. 6, 452-461.

Herrero, M., Thornton, P.K., Kruska, R. \& Reid, R.S., 2008. Systems dynamics and the spatial distribution of methane emissions from African domestic ruminants to 2030. Agric. Ecosyst. Environ. 126, 122-137.

Hristov, A.N., Oh, J., Lee, C., Meinen, R., Montes, F., Ott, T., Firkins, J., Rotz, A., Dell, C., Adesogan, A., Yang, W., Tricarico, J., Kebreab, E., Waghorn, G., Dijkstra, J. \& Oosting, S., 2013a. Mitigation of greenhouse gas emissions in livestock production - A review of technical options for non-C02 emissions. FAO Anim. Prod. Heal. 177, 226.

Hristov, A.N., Ott, T., Tricarico, J., Rotz, A., Waghorn, G., Adesogan, A., Dijkstra, J., Montes, F., Oh, J., Kebreab, E., Oosting, S.J., Gerber, P.J., Henderson, B., Makkar, H.P.S. \& Firkins, J.L., 2013b. SPECIAL TOPICS -- Mitigation of methane and nitrous oxide emissions from animal operations: III. A review of animal management mitigation options. J. Anim. Sci. 91, 5095-5113.

IPCC. 2014. Contribution of Working Groups I, II and III to the Fifth Assessment Report of the Intergovernmental Panel on Climate Change. Intergovernmental Panel on Climate Change.

Iwata, H. \& Okada, K., 2010. Greenhouse gas emissions and the role of the Kyoto Protocol. Environ. Econ. Policy Stud. 
16, 325-342.

Jiang, X., Sommer, S.G. \& Christensen, K.V., 2011. A review of the biogas industry in China. Energy Policy 39, 60736081.

Kavoi, M.M., Hoag, D.L. \& Pritchett, J., 2010. Measurement of economic efficiency for smallholder dairy cattle in the marginal zones of Kenya. Agric. Econ. 2, 122-137.

Key, N. \& Tallard, G., 2012. Mitigating methane emissions from livestock: A global analysis of sectoral policies. Clim. Change 112, 387-414.

Kinyua, M.N., Rowse, L.E. \& Ergas, S.J., 2016. Review of small-scale tubular anaerobic digesters treating livestock waste in the developing world. Renew. Sustain. Energy Rev. 58, 896-910.

Kirschke, S., Bousquet, P., Ciais, P., Saunois, M., Canadell, J.G., Dlugokencky, E.J., Bergamaschi, P., Bergmann, D., Blake, D.R., Bruhwiler, L., Cameron-Smith, P., Castaldi, S., Chevallier, F., Feng, L., Fraser, A., Heimann, M., Hodson, E.L., Houweling, S., Josse, B., Fraser, P.J., Krummel, P.B., Lamarque, J.-F., Langenfelds, R.L., Le Quéré, C., Naik, V., O'Doherty, S., Palmer, P.I., Pison, I., Plummer, D., Poulter, B., Prinn, R.G., Rigby, M., Ringeval, B., Santini, M., Schmidt, M., Shindell, D.T., Simpson, I.J., Spahni, R., Steele, L.P., Strode, S.A., Sudo, K., Szopa, S., van der Werf, G.R., Voulgarakis, A., van Weele, M., Weiss, R.F., Williams, J.E. \& Zeng, G., 2013. Three decades of global methane sources and sinks. Nat. Geosci. 6, 813-823.

Knapp, J.R., Laur, G.L., Vadas, P.A., Weiss, W.P. \& Tricarico, J.M., 2014. Invited review: Enteric methane in dairy cattle production: quantifying the opportunities and impact of reducing emissions. J. Dairy Sci. 97, 3231-61.

Köster, J.R., Cárdenas, L.M., Bol, R., Lewicka-Szczebak, D., Senbayram, M., Well, R., Giesemann, A. \& Dittert, K., 2015. Anaerobic digestates lower $\mathrm{N}_{2} \mathrm{O}$ emissions compared to cattle slurry by affecting rate and product stoichiometry of denitrification - $\mathrm{An} \mathrm{N}_{2} \mathrm{O}$ isotopomer case study. Soil Biol. Biochem. 84, 65-74.

Ledgard, S.F., Lieffering, M., Coup, D. \& O'Brien, B., 2011. Carbon footprinting of New Zealand lamb from the perspective of an exporting nation. Anim. Front. 1, 40-45.

Lehrman, A., Chatzopoulou, S., Feng, L., Forabosco, F., Elisabeth, J., Konstantinos, Karantininis Levander, F., Nicolia, A., Rydhmer, L., Röcklinsberg, H., Sandin, P., Sundström, J. \& Zhu, L.-H., 2014. Shaping our food - an overview of crop and livestock breeding. Mistra Biotech 1, 8-88.

Macleod, M., Gerber, P., Mottet, A., Tempio, G., Falcucci, A., Opio, C., Vellinga, T., Henderson, B. \& Steinfeld, H., 2013. Greenhouse gas emissions from pig and chicken supply chains - A global life cycle assessment. Food Agric. Organ. United Nations, 10-196.

Makkar, H.P.S., 2016. Smart livestock feeding strategies for harvesting triple gain-the desired outcomes in planet, people and profit dimensions: A developing country perspective. Anim. Prod. Sci. 56, 519-534.

Meissner, H.H., Scholtz, M.M. \& Engelbrecht, F.A., 2013a. Sustainability of the South African Livestock Sector towards 2050. Part 2: Challenges, changes and required implementations. S. Afr. J. Anim. Sci. 43, 298-319.

Meissner, H.H., Scholtz, M.M. \& Palmer, A.R., 2013b. Sustainability of the South African livestock sector towards 2050 Part 1: Worth and impact of the sector. S. Afr. J. Anim. Sci. 43, 282-297.

Meuwissen, T., Hayes, B. \& Goddard, M., 2016. Genomic selection: A paradigm shift in animal breeding. Anim. Front. 6, 6-14.

Mokolobate, M.C., Theunissen, A., Scholtz, M.M. \& Neser, F.W.C., 2014. Sustainable crossbreeding systems of beef cattle in the era of climate change. S. Afr. J. Anim. Sci. 44, S8-S11.

Mottet, A., Henderson, B., Opio, C., Falcucci, A., Tempio, G., Silvestri, S., Chesterman, S. \& Gerber, P. J., 2017. Climate change mitigation and productivity gains in livestock supply chains: insights from regional case studies. Reg. Environ. Chang. 17, 129-141.

Mushi, D.E., Eik, L.O., Bernués, A., Ripoll-Bosch, R., Sundstøl, F. \& Mo, M., 2015. Reducing GHG Emissions from Traditional Livestock Systems to Mitigate Changing Climate and Biodiversity. Springer Int. Publ. 19, 343-365.

Nicolazzi, E.L., Forabosco, F. \& Fikse, W.F., 2011. Assessment of the value of international genetic evaluations for yield in predicting domestic breeding values for foreign Holstein bulls. J. Dairy Sci. 94, 2601-2612.

O'Mara, F.P., 2011. The significance of livestock as a contributor to global greenhouse gas emissions today and in the near future. Anim. Feed Sci. Technol. 166-167, 7-15.

Opio, C., Gerber, P., Mottet, A., Falcucci, A., Tempio, G., MacLeod, M., Vellinga, T., Henderson, B. \& Steinfeld, H., 2013. Greenhouse gas emissions from ruminant supply chains - A global life cycle assessment. Food Agric. Organ. United Nations, 1-214.

Patra, A.K., 2012. Estimation of methane and nitrous oxide emissions from Indian livestock. J. Environ. Monit. 14, 26732684.

Patra, A.K., 2014. Trends and projected estimates of GHG emissions from indian livestock in comparisons with GHG emissions from world and developing countries. Asian-Australasian J. Anim. Sci. 27, 592-599.

Petersen, S.O., Andersen, A.J. \& Eriksen, J., 2012. Effects of cattle slurry acidification on ammonia and methane evolution during storage. J. Environ. Qual. 41, 88-94.

Petersen, S.O., Blanchard, M., Chadwick, D., Del Prado, A., Edouard, N., Mosquera, J. \& Sommer, S.G., 2013. Manure management for greenhouse gas mitigation. Animal 7, 266-282.

Pickering, N.K., Chagunda, M.G.G., Banos, G., Mrode, R., McEwan, J.C. \& Wall, E., 2015a. Genetic parameters for predicted methane production and laser methane detector measurements. J. Anim. Sci. 93, 11-20.

Pickering, N.K., Oddy, V.H., Basarab, J., Cammack, K., Hayes, B., Hegarty, R.S., Lassen, J., McEwan, J.C., Miller, S., Pinares-Patiño, C.S. \& de Haas, Y., 2015b. Animal board invited review: genetic possibilities to reduce enteric methane emissions from ruminants. Animal 9, 1431-1440.

Rearte, D.H. \& Pordomingo, A.J., 2014. The relevance of methane emissions from beef production and the challenges of 
the Argentinean beef production platform. Meat Sci. 98, 355-360.

Rust, J.M. \& Rust, T., 2013. Climate change and livestock production: A review with emphasis on Africa. S. Afr. J. Anim. Sci. 43, 256-267.

Samaniego, J. \& Schneider, H., 2015. Financing for climate change in Latin America and the Caribbean in 2014. ECLAC, 1-108.

Sarwar, F., Usman, M., Umar, S., Hassan, M., Rehman, A. \& Rashid, A., 2015. Some Aspects of Backyard Poultry Management Practices in Rural Areas of District Rawalpindi, Pakistan. Int. J. Livest. Res. 5, 14-20.

Scholtz, M.M., Furstenburg, D., Maiwashe, A., Makgahlela, M.L., Theron, H.E. \& der Westhuizen, J., 2010. Environmental-genotype responses in livestock to global warming: A Southern African perspective. S. Afr. J. Anim. Sci. 40, 408-413.

Scholtz, M.M., Maiwashe, A., Neser, F.W.C., Theunissen, A., Olivier, W.J., Mokolobate, M.C. \& Hendriks, J., $2013 a$. Livestock breeding for sustainability to mitigate global warming, with the emphasis on developing countries. S. Afr. J. Anim. Sci. 43, 269-281.

Scholtz, M.M., Mcmanus, C., Leeuw, K., Louvandini, H., Seixas, L., de Melo, C.B., Theunissen, A. \& Neser, F.W.C., 2013b. The effect of global warming on beef production in developing countries of the southern hemisphere. Nat. Sci. 5, 106-119.

Scholtz, M.M., Steyn, Y., Van Marle-Köster, E. \& Theron, H.E., 2012. Improved production efficiency in cattle to reduce their carbon footprint for beef production. S. Afr. J. Anim. Sci. 42, 450-453.

Scholtz, M.M., Van Ryssen, J.B.J., Meissner, H.H. \& Laker, M.C., 2013c. A South African perspective on livestock production in relation to greenhouse gases and water usage. S. Afr. J. Anim. Sci. 43, 247-254.

Shafer, S.R., Walthall, C.L., Franzluebbers, A.J., Scholten, M., Meijs, J., Clark, H., Reisinger, A., Yagi, K., Roel, A., Slattery, B., Campbell, I.D., McConkey, B.G., Angers, D.A., Soussana, J.-F. \& Richard, G., 2011. Emergence of the Global Research Alliance on Agricultural Greenhouse Gases. Carbon Manag. 2, 209-214.

Smith, J., Abegaz, A., Matthews, R.B., Subedi, M., Orskov, E.R., Tumwesige, V. \& Smith, P., 2014. What is the potential for biogas digesters to improve soil fertility and crop production in Sub-Saharan Africa? Biomass and Bioenergy 70, 58-72.

Sommer, S.G., Christensen, M.L., Schmidt, T. \& Jensen, L.S., 2013. Animal manure recycling: Treatment and management. John Wiley \& Sons.

Steinberg, M., 1999. Fossil fuel decarbonization technology for mitigating global warming. Int. J. Hydrogen Energy 24, 771-777.

Steinfeld, H., Gerber, P., Wassenaar, T.D., Castel, V. \& de Haan, C., 2006. Livestock's long shadow: environmental issues and options. Food Agric. Organiz. United Nations, Rome.

Teenstra, E., Vellinga, T., Aektasaeng, N., Amatayakul, W., Ndambi, A., Pelster, D., Germer, L., Jenet, A., Opio, C. \& Andeweg, K., 2014. Global assessment of manure management policies and practices. Wageningen UR Livest. Res. 844, 5-35.

Thien Thu, C.T., Cuong, P.H., Hang, L.T., Chao, N. Van, Anh, L.X., Trach, N.X. \& Sommer, S.G., 2012. Manure management practices on biogas and non-biogas pig farms in developing countries - Using livestock farms in Vietnam as an example. J. Clean. Prod. 27, 64-71.

Tindano, K., Moula, N., Traoré, A., Leroy, P. \& Antoine-Moussiaux, N., 2015. Characteristics and typology of sheep herding systems in the suburban area of Ouagadougou (Burkina Faso). Arch. Anim. Breed. 58, 415-423.

Török, T., Szabo, L.Z. \& Zsarnóczai, S.J., 2015. Methane reductions to moderate the global warming effects. Appl. Stud. Agribus. Commer. 9, 59-64.

Udo, H.M.J., Aklilu, H.A., Phong, L.T., Bosma, R.H., Budisatria, I.G.S., Patil, B.R., Samdup, T., \& Bebe, B.O., 2011. Impact of intensification of different types of livestock production in smallholder crop-livestock systems. Livest. Sci. 139, 22-29.

VanderZaag, A.C., Gordon, R.J., Jamieson, R.C., Burton, D.L. \& Stratton, G.W., 2009. Gas emissions from straw covered liquid dairy manure during summer storage and autumn agitation. Trans. ASABE 52, 599-608.

Vu, Q.D., Tran, T.M., Nguyen, P.D., Vu, C.C., Vu, V.T.K. \& Jensen, L.S., 2012. Effect of biogas technology on nutrient flows for small- and medium-scale pig farms in Vietnam. Nutr. Cycl. Agroecosystems 94, 1-13.

Wanapat, M. \& Kang, S., 2013. World buffalo production: Challenges in meat and milk production, and mitigation of methane emission.Pages 1-21 in Buffalo Bulletin. International Buffalo Information Center.

Weiler, V., Udo, H.M.J., Viets, T., Crane, T.A. \& De Boer, I.J.M., 2014. Handling multi-functionality of livestock in a life cycle assessment: The case of smallholder dairying in Kenya. Curr. Opin. Environ. Sustain. 8, 29-38.

Yogi, R.K., Verma, N.K., Jain, D.K. \& Rishikanta, S., 2015. Effect of bio-economic traits on market value of live goats: A case study of indigenous goat breeds. Indian J. Anim. Sci. 85, 805-809.

Zaman, M. \& Nguyen, M.L., 2012. How application timings of urease and nitrification inhibitors affect $\mathrm{N}$ losses from urine patches in pastoral system. Agric. Ecosyst. Environ. 156, 37-48. 